\title{
Structural and floristic typology of the forests in the forest-savanna mosaic of the Lopé National Park, Gabon
}

\author{
Florence Palla ${ }^{1}{ }^{*}$, Nicolas Picard ${ }^{2}$, Kate A. Abernethy ${ }^{3,4}$, Tharcisse Ukizintambara ${ }^{5}$, \\ Elizabeth C. White ${ }^{6}$, Bernard Riéra ${ }^{7}$, Jean-Paul Rudant ${ }^{8}$ \& Lee White ${ }^{3,4,9}$
}

\author{
${ }^{1}$ UPMC, Paris VI, BP 14 533, Libreville, Gabon \\ ${ }^{2}$ CIRAD, département ES, UPR 105, BP 4035, Libreville, Gabon \\ ${ }^{3}$ Institut de recherche en Écologie Tropicale, BP 13354, Libreville, Gabon \\ ${ }^{4}$ University of Stirling, Stirling, Scotland, UK-FK9 4LA, United Kingdom \\ ${ }^{5}$ BirdLife International Africa Partnership Secretariat, Icipe Campus, Kasarani Road, P.O. Box 3502 Nairobi 00100, Kenya \\ ${ }^{6}$ UNEP World Conservation Monitoring Centre, 219 Huntingdon Road, Cambridge, UK-CB3 ODL, United Kingdom \\ ${ }^{7}$ Laboratoire d'Ecologie Générale (MNHN), 4 avenue du Petit château, FR-91800, Brunoy, France \\ ${ }^{8}$ UPEMLV-Equipe GTMC, 5Bd Descartes, Champ sur Marne, FR-77454, Marne la Vallée, France \\ ${ }^{9}$ Agence Nationale des Parcs Nationaux, BP 20379, Libreville, Gabon \\ *Author for correspondence: pallaflorence@hotmail.com
}

\begin{abstract}
Background and aims - The Lopé National Park in Gabon, recently added to the UNESCO world heritage list, presents a mosaic of forest and savanna that dynamically changes. Conserving this landscape requires an understanding of the forest dynamics. This study aims at defining a forest typology at Lopé in relation with its dynamics.

Methods - Floristic and structural characteristics for 265 tree species belonging to 55 families were measured in 258 sampling plots in the Lopé National Park. Multivariate analysis of these data was used to partition the sampling plots into groups on the basis of their floristic or structural characteristics.

Key results - Five structural forest types and six floristic forest types were identified. This typology showed that the forests in the forest-savanna mosaic of Lopé organize themselves along a gradient of forest recovery, from young forests to mature forests. Typical pioneer species are associated with the youngest forest stages. The gradient on the species also corresponds to a geographical gradient on the sampling plots, associated with features like altitude, rocks, or hydrography.
\end{abstract}

Conclusions - Five forest types were defined on the basis of species abundances. The snapshot of forest types characterizes a dynamic process of forest regeneration.

Key words - abundance, canopy height, floristic groups, forest type, forest-savana mosaic, predominance, structural groups.

\section{INTRODUCTION}

Many tropical forests have once been disturbed by human activities, but after a long time following this disturbance, only a detailed examination of the structure and floristic composition of the vegetation can reveal a difference with pristine forests. The effect of selective logging on native tree diversity in tropical forests is a subject of speculation and of great current concern, but very limited data are available to assess its impact (Brown \& Gurevitch 2004). Although certain genera of high commercial interest have been selectively logged, the structure of the forest is not easy to predict without analysing the forest as a dynamic system. Rain forest is a complex community whose framework is provided by trees of many sizes. The consideration of the autoecology of individual tree species necessitates a reinterpretation of the much-discussed concept of stratification in the canopy (Whitmore 1975). The amount of new plant is low in the gap phase, increases to a maximum in the building phase, and declines during the mature phase. Patches of various sizes are the various phases of the forest growth cycle. The use of the stratification concept allows one discriminating species at different heights.

The dynamic nature of tropical forest can be illustrated by several changes (e.g. floristic composition), which means that different approaches are possible to analyse its structure after disturbance. One way is to analyze the size distribution of trees, or their stratification (Hallé et al. 1978). The forest 
is made up of a vast number of units interacting with each other. Despite that temperate forests are usually taken as examples to understand results in rain forests, basic concepts like tree height-diameter relationships (Schulz 1960) can be useful to understand the contrast of trees in closed and open environment, in relation with the vertical forest structure. To assess the role of a floristic community as a building element of the forest, the growth potential of tree species can be analysed (Hallé et al. 1978). Architecture indicates the population characteristics of forests and the change from one phase to another.

The tropical rain forest is no longer considered as a homogeneous entity, but rather as an heterogeneous ensemble of units with different ages, compositions, structures, and sizes (Aubréville 1938, Riéra et al. 1998). The silvatic mosaic and the stratification concept (Oldeman 1990) provide architectural criteria to analyse the organization of a forest system. When studying the vertical structure of forests, height classes can be defined together with groups of species with different height growth potential (Schulz 1960). Quoting Hallé et al. (1978), "in the vertically successive structural ensembles there is a mosaic of crowns shadowed by those above them. This systematic segregation may be taken as an indication that different species can achieve maximum photosynthetic activity under different light regimes". The characterization of vegetation groups relies on the most significant variables such as the number of individuals, their size, and their spatial distribution (Schulz 1960). Disturbances are phenomena that contribute to the structuring of the ecosystems. The intermediate disturbance hypothesis (Connell 1978) predicts a maximum species richness for intermediate disturbance frequencies and intensities. Two conceptual models explain the renewal of vegetation types: species replacements along the phases of succession, or species outbreaks in varying proportions depending on the time of forest reconstitution (Clements 1916, Lepart \& Escarré 1983).

In this study, available data from sampling plots surveyed in different vegetation formations in the Lopé National Park in Gabon, taking account of the history of selective logging (White 1996), was used to identify the characteristics of vegetation formations following disturbance. Multivariate analyses (PCA, CA, CCA) were used to test the hypothesis that human induced disturbances influence the floristic composition and the structure of vegetation formations. These results on the vegetation types in relation to disturbance are essential to implement conservation strategies in the National Park. This study thus addresses the two following questions: (i) What are the relevant structural and floristic variables to identify vegetation types in the Lopé National Park? (ii) Is the current forest pattern at Lopé an outcome of the interplay between the forest-savanna mosaic and recent disturbances? The relationship between forest structure and its floristic composition was analysed on the basis of species abundances in sampling plots.

\section{MATERIAL AND METHODS}

\section{Study site and sampling design}

Research was carried out in the Lopé National Park, central Gabon ( $\left.0^{\circ} 4^{\prime} \mathrm{S} 11^{\circ} 44^{\prime} \mathrm{E}\right)$. Our study site concerned the 300 $\mathrm{km}^{2}$ of savanna and forest-savanna mosaic along the northern and eastern limits of the park. Lopé has the lowest rainfall in Gabon (M.E.N. 1983). The mean annual rainfall taken at the SEGC research station in the centre of the study site is 1474 $\mathrm{mm}$ ( $\mathrm{SE} \pm 44.8$, from 1984 to 2004). There is a marked seasonality in the distribution of rainfall, with a long dry season between mid-June and mid-September whose severity and duration varies between years. A shorter and more variable dry season also occurs around January and February. Lopé's comparatively low rainfall is due to a rain shadow effect from the Massif du Chaillu mountains southwest of Lopé NP, and a low band of rainfall associated with the Ogooué river (White 2007). Temperature varies little throughout the year, although it is slightly cooler in the long dry season due to an almost constant cloud cover. A temperature logger placed in the open savanna at the SEGC research station recorded an overall mean daily temperature of $25.9^{\circ} \mathrm{C}(\mathrm{SE} \pm 0.06$ from January 2003 to December 2004), with temperatures ranging from $17.5^{\circ}-38.8^{\circ} \mathrm{C}$ throughout this period.

The relief consists to the South of a chain of convex hills dominated by the Okanda chain (450-850 $\mathrm{m}$ in height). This chain continues to the South where it reaches its highest point of about $900 \mathrm{~m}$. The North part is a former lake basin that was opened when the Ogooué river went through the Okanda chain. Erosion is strong on the slopes (UNESCO 2006). Vegetation in Lopé is a complex mosaic of plants association (White 1992). Three main forest types can be distinguished: gallery forests and bosques within the forest-savanna mosaic; young forests; and mature forests.

Available data collected at Lopé for different purposes were used in this study. Although the resulting sampling design was not optimal for our study, we ensured that this did not result in biased estimate of vegetation characteristics. The sampling design consisted of two types of sampling units: plots and transects. Plots were $800 \mathrm{~m}^{2}$ in area $(20 \mathrm{~m} \times 40 \mathrm{~m})$. All the trees with a diameter at breast height $(\mathrm{dbh})$ greater than $10 \mathrm{~cm}$ were inventoried in the plots. Their diameter and height were measured, and their species was identified. In total, 103 plots (totalling 8.24 ha) containing 3630 trees with $\mathrm{dbh} \geq 10 \mathrm{~cm}$ and 195 distinct species were inventoried between 1983 and 2008. Each plot was inventoried once (no longitudinal monitoring). Transects were $5 \mathrm{~km}$ long and their width depended on the dbh of the trees: trees with $10 \leq \mathrm{dbh}<$ $70 \mathrm{~cm}$ were inventoried as far as $2.5 \mathrm{~m}$ from the transect line (thus a width of $5 \mathrm{~m}$ ), whereas trees with $\mathrm{dbh} \geq 70 \mathrm{~cm}$ were inventoried as far as $25 \mathrm{~m}$ from the transect line (thus a width of $50 \mathrm{~m}$ ). Like for the plots, diameter and height of every inventoried tree were measured, and their species was identified. The location of each tree along the transect (distance since the origin of the transect) was also measured. In total, 5 transects (totalling 12.5 ha for $\mathrm{dbh}<70 \mathrm{~cm}$ and 62.5 ha for $\mathrm{dbh} \geq 70 \mathrm{~cm}$ ) containing 5175 trees and 182 distinct species were inventoried between 1989 and 2008.

A visual inspection of satellite images enabled us to classify the sampling units according to the main forest types. Young forests and mature forests could not be visually discriminated on satellite images, and were thus jointly classified as continuous forest. Plots were distributed as $28 \%$ in continuous forest, $27 \%$ in gallery forest, and $45 \%$ in bosques and savannas. Transects were all located in continuous forest. 
Four transects were located in formerly logged forest, while one transect $\left(n^{\circ} 5\right)$ was located in unlogged forest.

\section{Floristic and structural data}

To jointly analyse plot and transect data, we first converted transects into plots by truncating each $5 \mathrm{~km}$ long transect into 31 sections, each $160 \times 5 \mathrm{~m}$. Thus, plots and transect sections had the same area $\left(800 \mathrm{~m}^{2}\right)$, but not the same shape. As plot shape impacts the precision of estimation of the sampled quantities but not their expectation (e.g. Bormann 1953), differences in plot shapes have little influence in this study. Weighted means were used to correct for the variable width of the transects, as specified below. Two data sets were built from individual tree measurements in plots and transects: the floristic and the structural data set. Each data set had 258 rows that corresponded to the 258 sampling units (103 plots +155 transect sections).

The floristic data set gave the abundance of each species in each sampling unit. For transect sections, the abundance $N_{s}$ of a focal species $s$ in $800 \mathrm{~m}^{2}$ was computed as: $N_{s}=N_{<70, s}$ $+N_{\geq 70, s} / 10$, where $N_{<70, s}$ is the abundance of trees with $\mathrm{dbh}<$ $70 \mathrm{~cm}$ of species $s$ in the $160 \times 5 \mathrm{~m}$ transect section, whereas $N_{\geq 70, s}$ is the abundance of trees with $\mathrm{dbh} \geq 70 \mathrm{~cm}$ of species $s$ in the $160 \times 50 \mathrm{~m}$ transect section. The total number of distinct species found in plots and transects was 265 , thus resulting in 265 columns for the floristic data set.

The structural data set reported on 12 structural variables for each sampling unit: (1) total tree abundance $N$, that is the number of trees in $800 \mathrm{~m}^{2}$; (2) total basal area $B$ in $800 \mathrm{~m}^{2}$, computed as:

$B=(\pi / 4) \sum_{i=1}^{N} D_{i}^{2}$

where $D_{i}$ is the diameter of the $i$ th tree of the sampling unit; (3)-(8) tree abundances $N_{i}$ in 6 diameter classes, where $N_{i}$ $(i=1, \ldots, 5)$ is the number of trees with $5+(i-1) \times 10 \mathrm{~cm}<$ $\mathrm{dbh} \leq 5+i \times 10 \mathrm{~cm}$, and $N_{6}$ is the number of trees with $\mathrm{dbh}>$ $55 \mathrm{~cm}$ (hence $\sum_{i=1}^{6} N_{i}=N$ ); (9) mean height $\bar{H}$ within the $800 \mathrm{~m}^{2}$ sampling unit; (10) standard deviation $\sigma_{H}$ of height within the $800 \mathrm{~m}^{2}$ sampling unit; (11) maximal height $H_{\max }$; (12) identity of the species that has the maximal height within the $800 \mathrm{~m}^{2}$ sampling unit.

As transects had variable width, estimates derived from transect data had to be adjusted using varying size sampling estimators. The adjustment was not the same for cumulative estimates (such as tree density or basal area), for estimated means (such as mean height), and for estimated standard deviations. Hence three types of estimators were used. The estimator of a cumulative quantity $X$ in a transect section was:

$X=X_{<70}+X_{\geq 70} / 10$

where $X \equiv N, N_{i}$ or $B, X_{<70}$ was the value of $X$ when restricting to trees with $\mathrm{dbh}<70 \mathrm{~cm}$ in the $160 \times 5 \mathrm{~m}$ transect section, and $X_{\geq 70}$ was the value of $X$ when restricting to trees with $\mathrm{dbh}$ $\geq 70 \mathrm{~cm}$ in the $160 \times 50 \mathrm{~m}$ transect section. Mean values in transect sections were estimated as:

$\bar{X}=\frac{1}{N_{<70}+N_{\geq 70} / 10}\left(N_{<70} \bar{X}_{<70}+N_{\geq 70} \bar{X}_{\geq 70} / 10\right)$

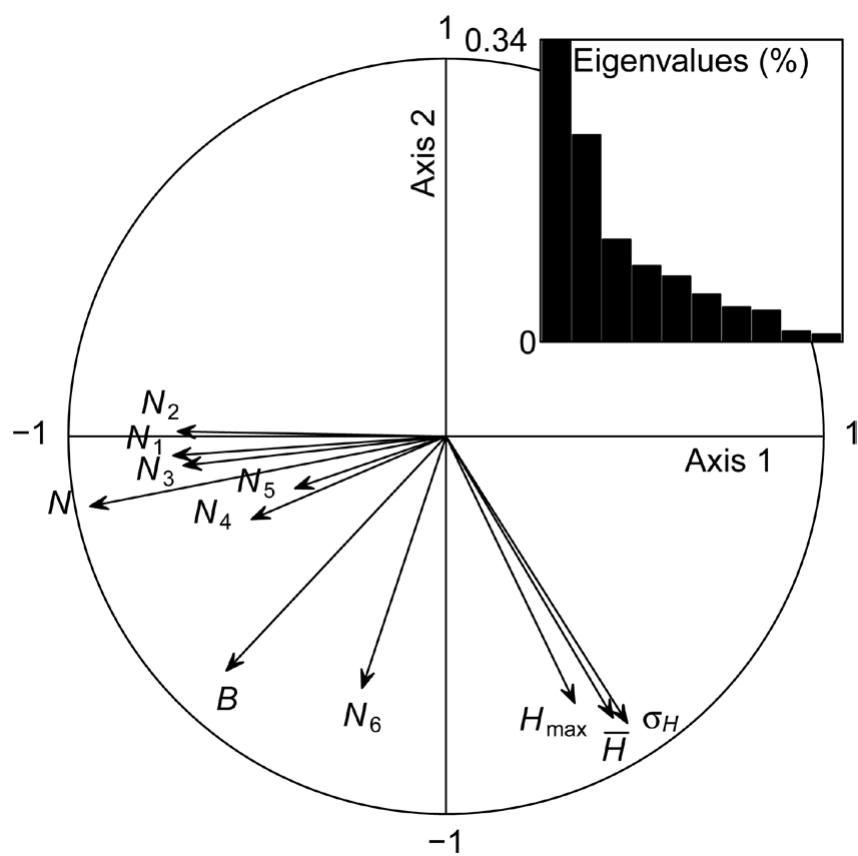

Figure 1 - Correlation circle of the principal component analysis of the structural variables for 258 sample plots at Lopé, Gabon. $N_{i}$ is the number of trees in the $i$ th diameter class, $N$ is the total number of trees, $B$ is basal area, $\bar{H}$ is mean height, $H_{\max }$ is maximal height, and $\sigma_{H}$ is the standard deviation of height.

where $X$ was height $H$ (so that $\bar{X} \equiv \bar{H}$ was mean height) or square height $H^{2}$ (so that $\bar{X} \equiv \overline{H^{2}}$ was mean square height), $X_{<70}$ was the mean of $X$ when restricting to trees with dbh $<70 \mathrm{~cm}$ in the $160 \times 5 \mathrm{~m}$ transect section, and $X_{\geq 70}$ was the mean of $X$ when restricting to trees with $\mathrm{dbh} \geq 70 \mathrm{~cm}$ in the $160 \times 50 \mathrm{~m}$ transect section. The standard deviation of height for transect sections was estimated as:

$\sigma_{H}={\sqrt{H^{2}}-\bar{H}^{2}}^{2}$

where mean height $\bar{H}$ and mean square height $\overline{H^{2}}$ were computed using (2). We checked that estimators (1)-(3) when applied to transect data did not bring any noticeable bias by comparing the distribution of each structural variable in plots and in transect sections. Similar distributions were indeed obtained. The structural data set thus had 12 columns.

\section{Multivariate analyses}

Analyses of structural data - Structural variables were analyzed using a principal component analysis (PCA) of the 258 $\times 11$ matrix giving the eleven quantitative structural variables for each sampling unit (Härdle \& Simar 2003, chapter 9). The PCA was complemented with a hierarchical cluster analysis to partition the 258 sampling plots into groups (Härdle \& Simar 2003, chapter 11). This cluster analysis used the Euclidean metric to measure differences between plots and Ward's method to cluster groups (Ward 1963). As these groups of plots were based on structural variables, we hereafter call them the 'structural groups'. Mean values of the structural variables for each structural group were computed. 
Table 1 - Mean values of the structural variables for each group of plots.

The groups were defined from structural variables. $N_{i}$ is the number of trees in the $i$ th diameter class, $N$ is the total number of trees, $B$ is basal area, $\bar{H}$ is mean height, $H_{\max }$ is maximal height, $\sigma_{H}$ is the standard deviation of height, CI is Clapham index.

\begin{tabular}{lllllll}
\hline $\begin{array}{l}\text { structural } \\
\text { variable }\end{array}$ & unit & \multicolumn{2}{l}{ structural group } & & & \\
\hline$N_{1}$ & & 1 & 2 & 3 & 4 & 5 \\
$N_{2}$ & $\mathrm{ha}^{-1}$ & 108.7 & 117.3 & 152.9 & 142.1 & 415.6 \\
$N_{3}$ & $\mathrm{ha}^{-1}$ & 96.0 & 83.2 & 101.9 & 151.0 & 241.7 \\
$N_{4}$ & $\mathrm{ha}^{-1}$ & 45.0 & 40.7 & 51.9 & 69.2 & 133.3 \\
$N_{5}$ & $\mathrm{ha}^{-1}$ & 27.5 & 31.6 & 38.5 & 33.8 & 75.0 \\
$N_{6}$ & $\mathrm{ha}^{-1}$ & 11.2 & 18.6 & 8.2 & 30.1 & 37.5 \\
$N$ & $\mathrm{ha}^{-1}$ & 18.9 & 50.8 & 27.4 & 23.0 & 55.2 \\
$B$ & $\mathrm{ha}^{-1}$ & 307.2 & 342.1 & 380.8 & 449.1 & 958.3 \\
$\bar{H}$ & $\mathrm{~m}^{2} \mathrm{ha}^{-1}$ & 20.3 & 38.8 & 28.8 & 29.2 & 57.6 \\
$H_{\max }$ & $\mathrm{m}$ & 15.6 & 20.5 & 11.4 & 15.6 & 13.3 \\
$\sigma_{H}$ & $\mathrm{~m}$ & 37.8 & 41.5 & 19.7 & 32.9 & 30.5 \\
\hline
\end{tabular}

The description of structural groups was complemented with two additional descriptors, not included in the PCA. First, the distribution of the species with the maximal height within each plot was computed for each group. These are the species that form the canopy. Second, Clapham index was computed for each structural group from the counts of trees in each plot (Pielou 1969). If $n_{k}$ is the number of plots in group $k$, and $N_{j k}\left(j=1, \ldots, n_{k}\right)$ is the number of trees in the $j$ th plot of group $k$, Clapham index (CI) for group $k$ is defined as the empirical variance of $N_{1 k}, \ldots, N_{n k^{k}}$ divided by its mean. If $N_{j k}$ is distributed as a Poisson variable, then CI equals one. Clapham index thus is a rough index to characterize the spatial pattern of trees, where over-dispersion with respect to the Poisson distribution $(\mathrm{CI}>1)$ means that trees have a clustered spatial pattern, whereas under-dispersion with respect to the Poisson distribution $(\mathrm{CI}<1)$ means that trees have a regular spatial pattern. Departure from the null hypothesis of random spatial pattern $(\mathrm{CI}=1)$ was tested using a Monte Carlo test with $\mathrm{CI}$ as the test statistic.

The relationship between the structural groups and the type of sampling unit (either a plot or a part of the 1st, 2nd, ..., 5th transect) was tested using a $\chi^{2}$ test. The relationship between the structural groups and the main forest types (bosque, gallery forest, continuous forest) was also tested using a $\chi^{2}$ test.

Analyses of floristic data - Floristic data were analyzed using a correspondence analysis (CA) of the $258 \times 265$ table giving the abundance of each species in each sampling unit (Härdle \& Simar 2003, chapter 13). The same analysis was repeated after collapsing the species abundances into family abundances. As the 265 species belonged to 55 distinct families, a $258 \times 55$ table of family abundances in each sampling unit was analyzed.

The CA was complemented with a hierarchical cluster analysis to partition the 258 sampling plots into groups. This cluster analysis used the Euclidean distance between plots in the plane formed by the first two axes of the CA, and Ward's method to cluster groups. As these groups of plots were based on floristic variables, we hereafter call them the 'floristic groups'.

The relationship between the floristic groups and the type of sampling unit (either a plot or a part of the 1 st, $2 \mathrm{nd}, \ldots ., 5$ th transect) was tested using a $\chi^{2}$ test. The relationship between the floristic groups and the main forest types (bosque, gallery forest, continuous forest) was also tested using a $\chi^{2}$ test.

Relationship between structural and floristic data - The relationship between structural and floristic data was first investigated using a canonical correspondence analysis (CCA) of the pair of tables, one giving the abundance of each species, and the other giving the structural variables in each sampling unit. CCA consists in replacing the observed abundance $A_{\mathrm{s}}$ of species $s$ in a given plot by its abundance predicted by the multiple regression on structural variables: $A_{s}=a_{s}+\varepsilon_{s}$, where $\varepsilon_{s}$ is the residual error,

$a_{s}=\beta_{0 s}+\sum_{i=1}^{6} \beta_{i s} N_{i}+\beta_{7 s} N+\beta_{8 s} B+\beta_{9 s} \bar{H}+\beta_{10 s} H_{\max }+\beta_{11 s} \sigma_{H}$

and the $\beta_{i s}(i=1, \ldots, 11)$ are the estimated regression coefficients. Then a correspondence analysis on the table of predicted abundances $a_{s}$ is performed (Couteron et al. 2003). The inertia of the table of predicted abundances $a_{s}$ can be compared to the inertia of the table of observed abundances $A_{s}$. Moreover, we can test if the former is significantly different from zero using a Monte Carlo test based on random permutations of the table rows (Couteron et al. 2003).

Second, a $\chi^{2}$ test was performed on the contingency table that cross-tabulates the 258 sampling units between structural groups and floristic groups, to test for the relationship between these two groupings. Analyses of variance of the structural variables with respect to the floristic groups were conducted to test for differences in structural variables between floristic groups. Conversely, analyses of variance of the species abundances with respect to the structural groups 


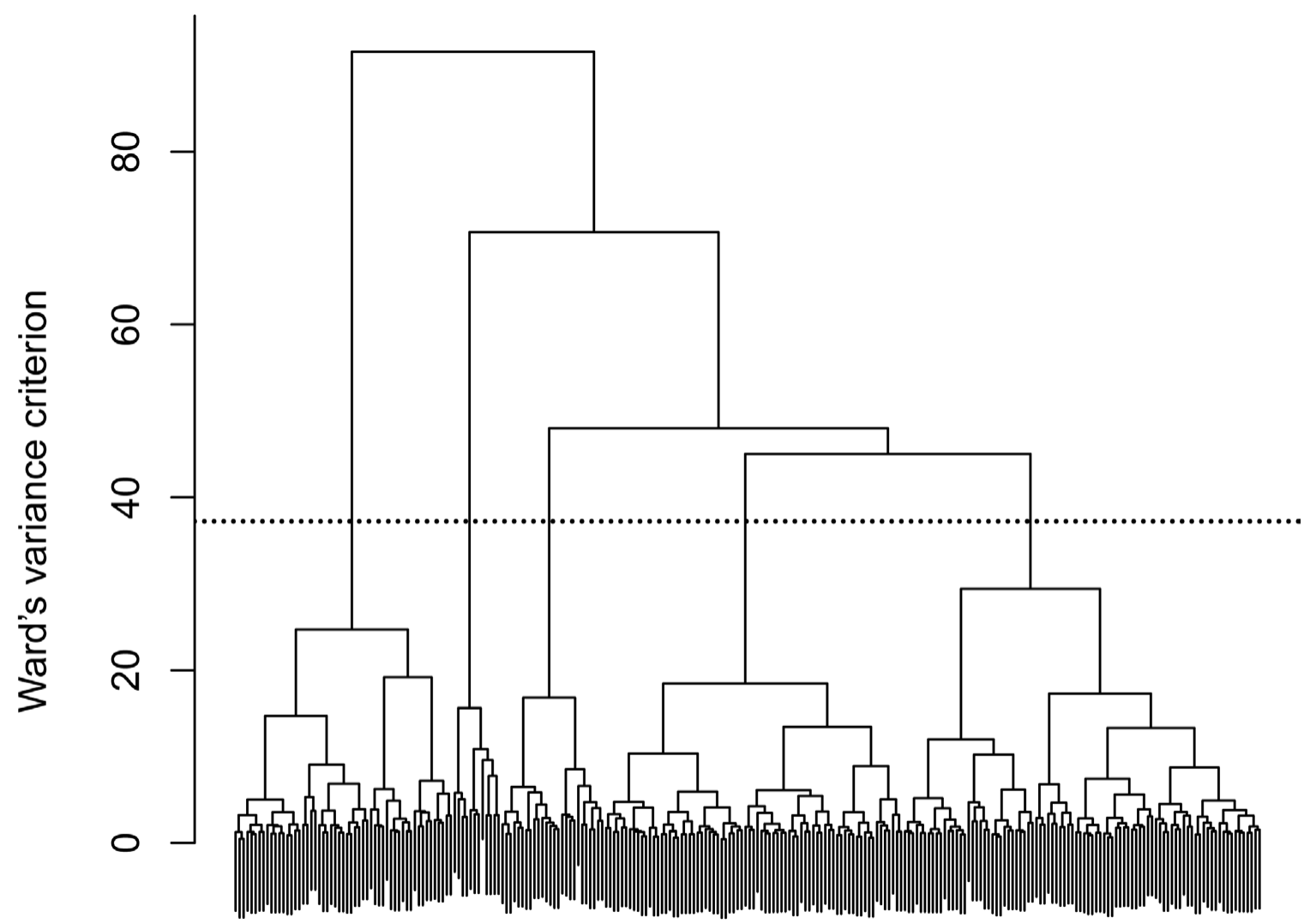

\section{Sampling plot}

Figure 2 - Dendrogram of the hierarchical cluster analysis of the 258 sample plots at Lopé, Gabon on the basis of their structural variables. The dotted line shows where the dendrogram was cut to define the structural groups.

were conducted to test for differences in species abundances between structural groups.

Additional multivariate analyses of floristic and structural data were performed but are not reported here since they brought little additional information. They can be found as supplementary data.

\section{RESULTS}

\section{Structural characteristics}

Two groups of positively correlated variables were shown up by the PCA of structural variables (fig. 1). The first group gathers $N$ and $N_{1}-N_{4}$ and explains the first axis of the PCA. It thus corresponds to tree density, with the strongest contribution to the total density of the smallest diameter classes. The second group gathers the variables related to height $(\bar{H}$, $H_{\text {max }}$, and $\sigma_{H}$ ) and explains the second axis of the PCA. It thus corresponds to the height of the canopy. Variables $B$ and $N_{6}$, that are positively correlated, stand in between: large basal areas are found when the plots contain many large trees, and many large trees also means a high canopy. The dendrogram of the hierarchical cluster analysis on structural variables (fig. 2) suggested to partition the 258 sampling units into five groups. Whatever the group, Clapham index was significantly greater than one (table 1), with $p$-values always less than $1 \%$.
Hence, the spatial pattern of trees was always significantly clustered at the scale of $800 \mathrm{~m}^{2}$. Using the mean values of the structural variables (table 1), the structural groups could be interpreted as follows:

Group 1 - It gathers 75 sampling units, and is characterized by the lowest density (whether one considers the total density or the density per class) and the lowest basal area. Canopy height is medium, and spatial clustering is the weakest. The plots of this group thus are low-density plots. The species that form the canopy are varied (23 distinct species), with a dominance of Aucoumea klaineana Pierre (18.8\% of the plots), Dacryodes buettneri (Engl.) H.J.Lam (16.7\%), and Lophira alata Banks ex Gaertn. (10.4\%).

Group 2 - It gathers 55 sampling units, and is characterized by the highest canopy height (whether one considers mean height, maximum height, or height standard deviation). It has few trees in the lowest diameter classes $\left(N_{1}-N_{3}\right)$, but many trees in the largest diameter class $\left(N_{6}\right)$, and a quite elevated basal area, thus resulting in the highest ratio of basal area over tree density. The plots of this group thus are low-density plots but with the presence of large trees with a high canopy. The canopy species do not vary much (thirteen species), with an overwhelming dominance of Aucoumea klaineana Pierre ( $48.9 \%$ of the plots; the second commonest species being Pterocarpus soyauxii Taub. with $13.3 \%$ ). 
Table 2 - Analysis of variance of the structural variables with respect to the floristic groups at Lopé, Gabon.

Letters indicate the different levels according to Tukey's multiple paired comparison test. $N_{i}$ is the number of trees in the $i$ th diameter class, $N$ is the total number of trees, $B$ is basal area, $\bar{H}$ is mean height, $H_{\max }$ is maximal height, and $\sigma_{H}$ is the standard deviation of height.

\begin{tabular}{|c|c|c|c|c|c|c|c|c|c|}
\hline \multirow{2}{*}{$\begin{array}{l}\text { structural } \\
\text { variable }\end{array}$} & \multirow[t]{2}{*}{ unit } & \multicolumn{6}{|c|}{ mean value within floristic group } & \multirow[b]{2}{*}{$\mathrm{F}$} & \multirow[b]{2}{*}{$p$-value } \\
\hline & & 1 & 2 & 3 & 4 & 5 & 6 & & \\
\hline$N_{1}$ & $\mathrm{ha}^{-1}$ & $157.9^{\mathrm{b}}$ & $135.8^{\mathrm{ab}}$ & $156.8^{\mathrm{ab}}$ & $111.5^{\mathrm{a}}$ & $148.8^{\mathrm{ab}}$ & $250^{\mathrm{ab}}$ & 2.73 & 0.02 \\
\hline $\mathrm{N}_{2}$ & $\mathrm{ha}^{-1}$ & $110.9^{\mathrm{a}}$ & $100.6^{\mathrm{a}}$ & $121.6^{\mathrm{ab}}$ & $122.9^{\mathrm{ab}}$ & $154.1^{\mathrm{bc}}$ & $258.3^{\mathrm{c}}$ & 7.27 & $<0.001$ \\
\hline$N_{3}$ & $\mathrm{ha}^{-1}$ & $54.1^{\mathrm{a}}$ & $48.3^{\mathrm{a}}$ & $80.7^{\mathrm{a}}$ & $58.1^{\mathrm{a}}$ & $64.1^{\mathrm{a}}$ & $150^{\mathrm{b}}$ & 6.19 & $<0.001$ \\
\hline$N_{4}$ & $\mathrm{ha}^{-1}$ & 35.5 & 32.5 & 34.1 & 33.3 & 30.6 & 75 & 1.76 & 0.123 \\
\hline$N_{5}$ & $\mathrm{ha}^{-1}$ & 18.4 & 21.1 & 17 & 20.8 & 20.3 & 50 & 1.74 & 0.125 \\
\hline$N_{6}$ & $\mathrm{ha}^{-1}$ & $31.9^{\mathrm{a}}$ & $36.6^{\mathrm{a}}$ & $42^{\mathrm{ab}}$ & $24.5^{\mathrm{ab}}$ & $17.1^{\mathrm{b}}$ & $41.7^{\mathrm{ab}}$ & 4.17 & 0.001 \\
\hline$N$ & $\mathrm{ha}^{-1}$ & $408.7^{\mathrm{a}}$ & $375^{\mathrm{a}}$ & $452.3^{\mathrm{a}}$ & $371.2^{\mathrm{a}}$ & $434.9^{\mathrm{a}}$ & $825^{\mathrm{b}}$ & 4.92 & $<0.001$ \\
\hline$B$ & $\mathrm{~m}^{2} \mathrm{ha}^{-1}$ & $33.1^{\mathrm{ab}}$ & $31^{\mathrm{ab}}$ & $34.1^{\mathrm{ab}}$ & $26.2^{\mathrm{a}}$ & $24.9^{\mathrm{a}}$ & $54.2^{\mathrm{b}}$ & 4.34 & 0.001 \\
\hline $\bar{H}$ & $\mathrm{~m}$ & $14.6^{b}$ & $18.7^{\mathrm{a}}$ & $11.6^{\mathrm{b}}$ & $15.5^{\mathrm{b}}$ & $15.1^{\mathrm{b}}$ & $12.8^{\mathrm{ab}}$ & 11.71 & $<0.001$ \\
\hline$H_{\max }$ & $\mathrm{m}$ & $27.9^{c}$ & $38.8^{\mathrm{a}}$ & $24.5^{\mathrm{bc}}$ & $37.9^{\mathrm{a}}$ & $36.3^{\mathrm{ab}}$ & $21^{\mathrm{abc}}$ & 11.28 & $<0.001$ \\
\hline$\sigma_{H}$ & $\mathrm{~m}$ & $6.5^{\mathrm{c}}$ & $9.4^{\mathrm{a}}$ & $5.6^{\mathrm{bc}}$ & $8^{\mathrm{b}}$ & $7.7^{\mathrm{bc}}$ & $4.3^{\mathrm{abc}}$ & 12.08 & $<0.001$ \\
\hline
\end{tabular}

Group 3 - It gathers 26 sampling units, and is characterized by the lowest canopy height (whether one considers mean height, maximum height, or height standard deviation). Its tree density is medium (whether one considers the total density or the density per class), and its basal area is medium as well. Spatial clustering is the strongest. The canopy species are dominated by Lophira alata Banks ex Gaertn. (16.0\% of the plots) and Craibia laurentii De Wild. (12.0\%), for a total of eighteen distinct species.

Group 4 - It is the largest group with ninety sampling units, but is also the group without any specific feature: all struc-

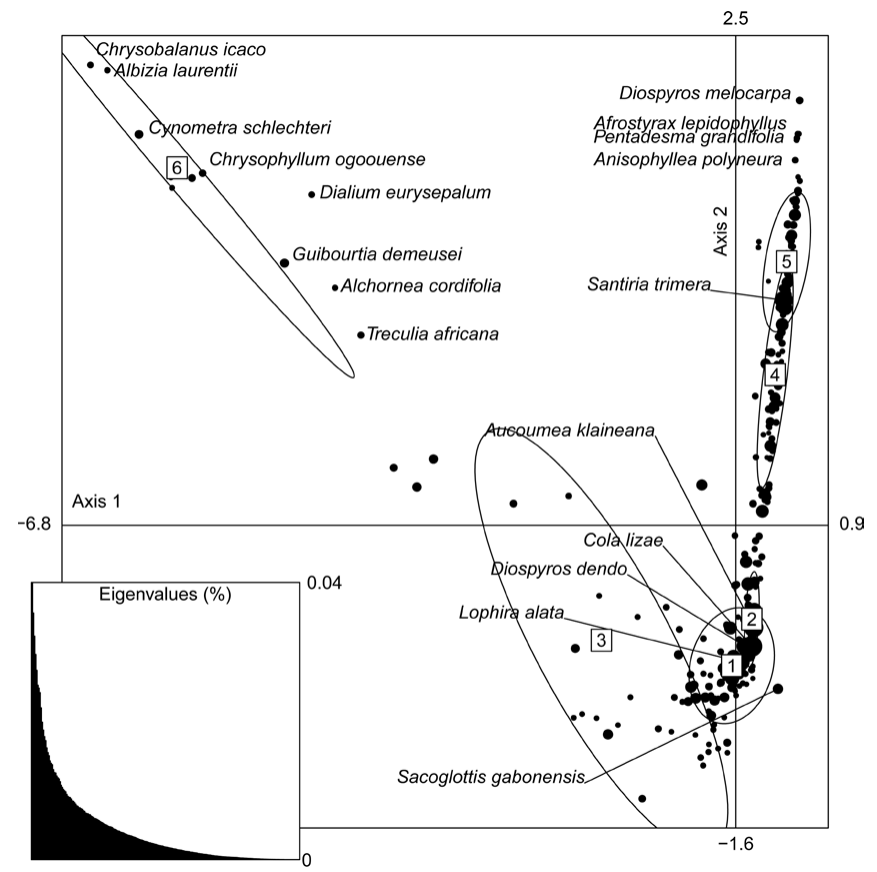

Figure 3 - Projection of species (dots) and of floristic groups (ellipses) on the first two axes of the correspondence analysis of the species abundances at Lopé, Gabon. The size of dots is proportional to the square root of species abundances. tural variables take medium values. The canopy species are varied (28 distinct species), with a dominance of Aucoumea klaineana Pierre (23.6\% of the plots), Dacryodes buettneri (Engl.) H.J.Lam (7.3\%), and Lophira alata Banks ex Gaertn. $(7.3 \%)$, which are the same species than in group 1 .

Group 5 - It gathers twelve plots, and is characterized by the highest density (whether one considers the total density or the density per class) and the highest basal area. Canopy height is medium. The plots of this group thus are high-density plots. The species that form the canopy are limited to seven species, with a dominance of Hylodendron gabunense Taub. (30\% of the plots) and Aucoumea klaineana Pierre (20\% of the plots). The structural groups turned out to be significantly related to the type of sampling unit $\left(\chi^{2}=225.0, p\right.$-value $\left.<0.001\right)$ : structural group 2 was strongly associated with transect 2 , group 3 was associated with plots, and group 4 was weakly associated with transect 4 . The structural groups were also significantly related to the main forest types $\left(\chi^{2}=111.9, p\right.$ value $<0.001)$ : structural groups 3 and 5 were jointly associated with bosques and gallery forests, but continuous forest did not show any specific relation to any structural group.

\section{Floristic characteristics}

The CA of species abundances presented a Guttman effect (fig. 3) that denoted a gradient along the first axis of the CA. The most abundant species (Cola lizae N.Hallé, Santiria trimera (Oliv.) Aubrév., Aucoumea klaineana Pierre, Lophira alata Banks ex Gaertn.) were found at the centre of this gradient, the extremities of the gradient being occupied by species that were globally rare but locally abundant in some sampling units.

The dendrogram of the hierarchical cluster analysis on species abundances (fig. 4) suggested to divide the 258 sampling units into six floristic groups. These floristic groups ordered along the gradient corresponding to the first axis of the CA (fig. 3). The floristic groups were significantly related to the type of sampling unit $\left(\chi^{2}=343.4, p\right.$-value $\left.<0.001\right)$. Plots were associated with floristic groups 1, 3 and 6 , which 
corresponded to the left-hand side of the gradient. Transects 1 and 2 were almost exclusively found in floristic group 2 (at the centre of the gradient), whereas transects 3-5 were almost exclusively found in floristic groups 4 and 5 (to the right-hand side of the gradient). The gradient of the CA thus corresponded to a geographical gradient of forest types, from plots to transects 3-5 through transects 1 and 2 (fig. 5).

The floristic groups were also significantly related to the main forest types $\left(\chi^{2}=198.0, p\right.$-value $\left.<0.001\right)$ : floristic group 1 was strongly associated with bosques, floristic groups 3 and 6 were strongly associated with gallery forests, while continuous forest did not show any specific relation to any floristic group.

When analyzing family abundances rather than species abundances, a strong opposition was found between the $\mathrm{Hu}$ miriaceae on the one hand, and all other families on the other hand. At Lopé, the Humiriaceae were represented by a single species, Sacoglottis gabonensis (Baill.) Urb. This species was located in the middle of the gradient of the CA (fig. 3). It was globally rare (it was found in fifteen sampling units out of 258) but, when it was found, it was abundant.

\section{Relationship between structural and floristic characteristics}

When performing the CCA, the total inertia of the table of predicted abundances was 1.44 , to be compared to 21.3 for the table of observed abundances. Yet this value was significantly different than zero ( $p$-value $<0.001)$, thus indicating a significant relationship between the structural variables and the floristic characteristics. The correlation circle of the CCA was similar, up to a rotation, to the correlation circle of the PCA (fig. 6). The first axis of the CCA was positively correlated with density and negatively correlated with canopy height. Its second axis discriminated dense plots with a high canopy from low-density plots with a low canopy. The projection of species on the first two axes of the CCA was very different from their projection on the first two axes of the CA, thus indicating that the gradient along the first axis of the CA could not be explained by structural variables (fig. 7). The most abundant species (Cola lizae N.Hallé, Santiria trimera (Oliv.) Aubrév., Aucoumea klaineana Pierre, Lophira alata Banks ex Gaertn.) were found in the left part of figure 7 . They were thus predominantly found in low-density plots with a high canopy, which corresponds to the description of structural group 2 .

Structural groups and floristic groups were significantly related $\left(\chi^{2}=148.5, p\right.$-value $\left.<0.001\right)$. A correspondence was found between structural groups 5, 2, 3 and floristic groups 6 , 2,1 , respectively. A weaker correspondence was also found between structural groups 1, 3, 4 and floristic groups 4, 3, 5

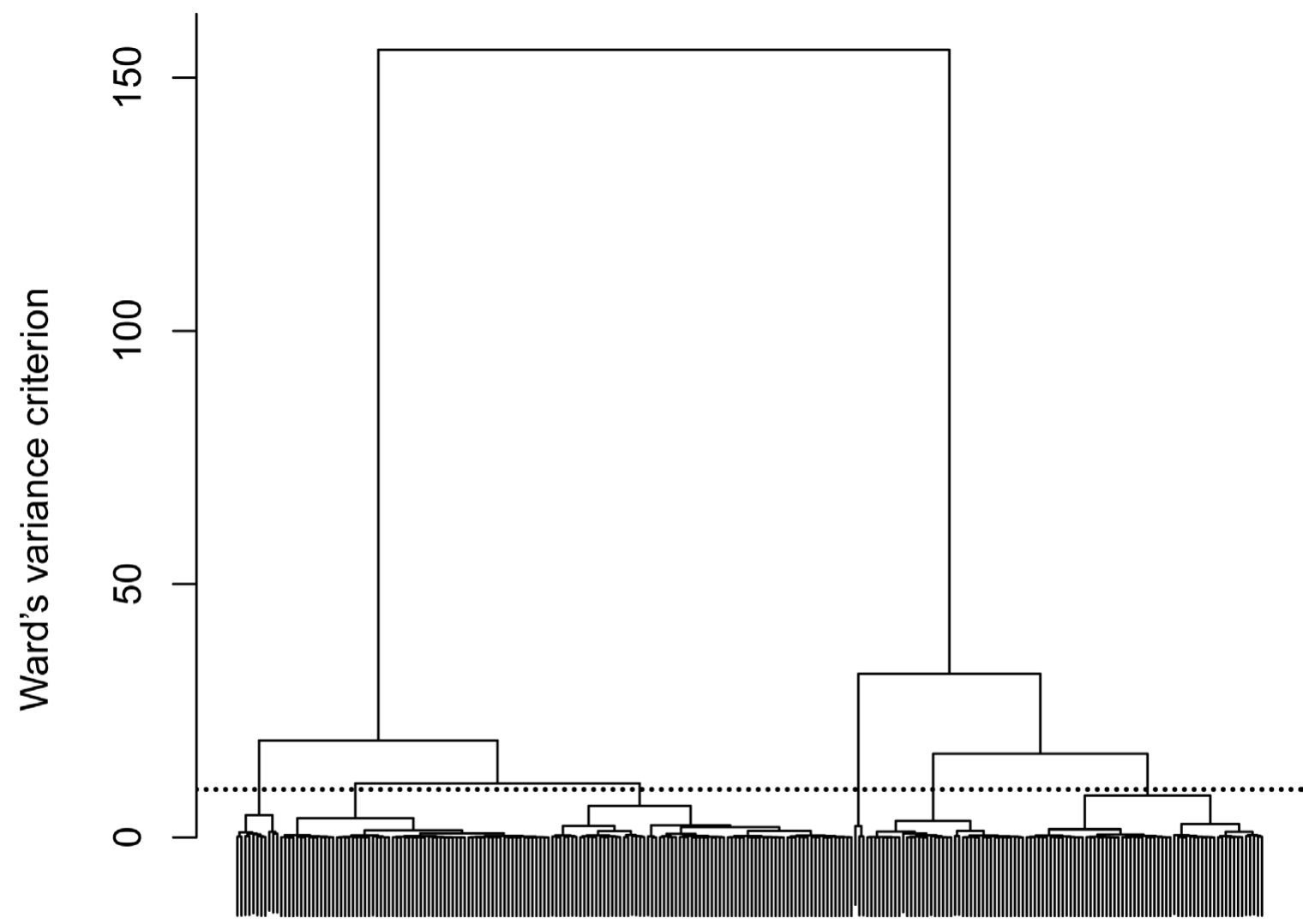

\section{Sampling plot}

Figure 4 - Dendrogram of the hierarchical cluster analysis of the 258 sample plots at Lopé, Gabon on the basis of their species abundances. The dotted line shows where the dendrogram was cut to define the floristic groups. 


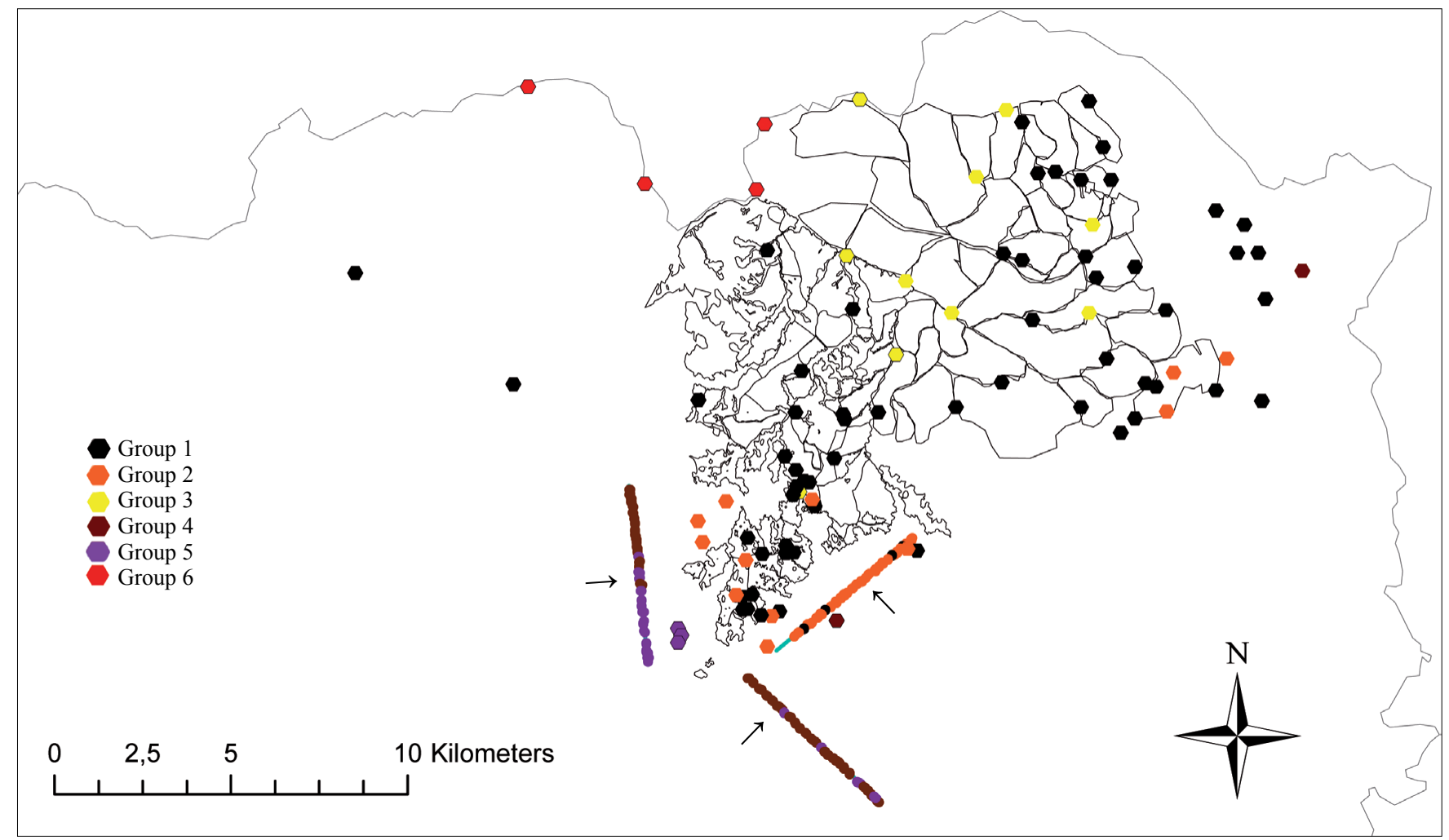

Figure 5 - Location of the sampling plots in the Lopé National Park, Gabon, together with the six floristic groups to which they belong. In grey: Lopé National Park border; in black: savanna border; arrows indicates the three transects.

respectively. These correspondences were consistent with the associations previously identified between either structural or floristic groups and the type of sampling unit. For instance, structural group 2 was associated with transect 2, and corresponded to floristic group 2 that was also associated with transect 2.

With the exception of $N_{4}$ and $N_{5}$, all structural variables were significantly different between floristic groups (table 2 ). As the correspondence between structural groups and floristic groups was not perfect, the structural characteristics of the floristic groups were not as contrasted as those of the structural groups. Yet some agreement was found between the structural characteristics of the two groupings. For instance, floristic group 2 was characterized by a low density and a large canopy height (table 2), in the same way as structural group 2 (table 1) to which it was associated. Another example is floristic group 6 that was characterized by a high density and a large basal area (table 2), in the same way as structural group 5 (table 1) to which it was associated.

Among the 265 species found at Lopé, 82 had significantly different abundances between the five structural groups at $5 \%$ level. This enabled us identifying the species specific to each structural group. Thus, the description of the structural groups given before could be complemented with the following floristic information:

- Group 1 had Desbordesia glaucescens (Engl.) Tiegh., Dialium guineense Willd., Carapa procera DC., Grewia coriacea Mast., and Scyphocephalium mannii (Benth.) Warb. as characteristic species.
- Group 2 had Cola lizae N.Hallé, Aucoumea klaineana Pierre, Lophira alata Banks ex Gaertn., Diospyros polystemon Gürke, Xylopia hypolampra Mildbr., Hypodaphnis zenkeri (Engl.) Stapf, and Berlinia bracteosa Benth. as characteristic species. This result had already been partially given by the CCA.

- Group 3 had Uapaca guineensis Müll.Arg, Craibia laurentii De Wild., Paropsia grewioides Welw. ex Mast., Pseudospondias microcarpa (A.Rich.) Engl. var, Milicia excelsa (Welw.) C.C.Berg, Aidia ochroleuca (K.Schum.) E.M.A.Petit, Detarium macrocarpum Harms, and Chytranthus talbotii (Baker f.) Keay as characteristic species.

- Group 4 had Santiria trimera (Oliv.) Aubrév., Centroplacus glaucinus Pierre, Strombosiopsis tetrandra Engl., Dacryodes klaineana (Pierre) H.J.Lam, and Coula edulis Baill. as characteristic species.

- Group 5 had Diospyros dendo Welw. ex Hiern, Pentaclethra eetveldeana De Wild. \& T.Durand, Diospyros zenkeri (Gürke) F.White, Diospyros iturensis (Gürke) Letouzey \& F.White, Xylopia aethiopica (Dunal) A.Rich, Guibourtia demeusei (Harms) J.Léonard, Cynometra schlechteri Harms, Dialium lopense Breteler, Antidesma vogelianum Müll.Arg, Pachystela brevipes (Baker) Baill. ex Engl., Aphanocalyx djumaensis (De Wild.) J.Léonard, Irvingia gabonensis (Aubry-Lecomte ex O'Rorke) Baill., Baikiaea robynsii Ghesq. ex Laing, Ongokea gore (Hua) Pierre, Elaeis guineensis Jacq., Cathormion altissimum (Hook.f.) Hutch. \& Dandy, Dialium eurysepalum Harms, 


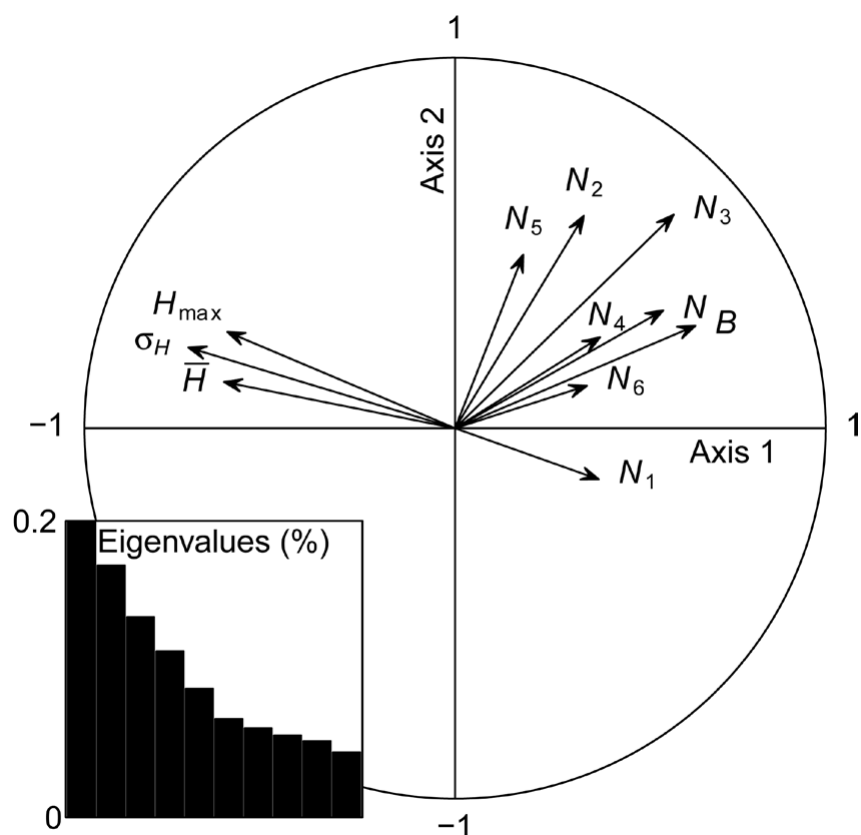

Figure 6 - Correlations between the structural variables and the first two axes of the canonical correspondence analysis of the species abundances at Lopé, Gabon. $N_{i}$ is the number of trees in the $i$ th diameter class, $N$ is the total number of trees, $B$ is basal area, $\bar{H}$ is mean height, $H_{\max }$ is maximal height, and $\sigma_{H}$ is the standard deviation of height.

Psychotria venosa (Hiern) E.M.A.Petit, Vitex doniana Sweet, Pycnanthus angolensis (Welw.) Warb., Connarus griffonianus Baill., Ficus subsagittifolia Mildbr. ex C.C.Berg, Holarrhena floribunda (G.Don) Dur. \& Schinz, Millettia griffoniana Baill., Monanthotaxis klainei (Pierre ex Engl. \& Diels) Verdc., Oxyanthus unilocularis Hiern, Rothmannia whitfieldii (Lindl.) Dandy, and Uapaca heudelotii Baill. as characteristic species.

\section{DISCUSSION}

Vegetation at Lopé could be classified into five or six types depending on whether these types were defined from structural or floristic characteristics. Although structural and floristic groups were significantly related, they reflected different information. In particular, floristic groups were ordered along a gradient that could not be explained by structural variables. When using a classification method based on floristic data with a weight for each species proportional to its abundance, this gradient vanishes and floristic groups become more similar to structural groups.

\section{Structural characteristics}

In terms of tree density, a strong opposition was found between the many individuals in the young stages and those of the highest diameter classes. The significant relationship between the number of trees in diameter class $N_{6}$ and basal area suggests that the corresponding species are commercial species that were not removed following selective logging. The species that reach a large diameter identify with those that are dominant in the canopy, in terms of basal area, height, or abundance. As these species are also the ones that are found in the plots with the highest basal areas, we can conclude that both basal and density are indicators of the structure of the vegetation groups in our study. These results contrast with those of Schulz (1960) regarding the weight of basal area: "I am not sure that its classificatory value is really greater than that of the number of individuals" wrote Schulz when he described the floristic composition of Mapane forest.

In terms of height, an opposition was found between the plots with a high density and a high canopy, and the plots with a low density and a low canopy. The observed architecture was heterogeneous, which is surprising since, in general, a high density corresponds to small diameters and low height. The identification of the species with the maximum height (six species) suggests that their ability to quickly cover the canopy would be bound to their temperament. These species have developed specific strategies with respect to light, to grow as fast as possible in reference to the concept of ecotope (Oldeman 1974). This mainly concerns Aucoumea klaineana Pierre, which was found as a dominant canopy species in four of the five structural groups, and also Lophira alata Banks ex Gaertn. and Dacryodes buettneri (Engl.) H.J.Lam. When considering the maximum height and the mean height, two structural sets in the sense of Oldeman (1990) can be clearly distinguished: two arborescent layers including the trees of the higher layer on the one hand, and emergent trees on the other hand. Similar results were found in Ivory Coast (Devineau 1975, 1984, 1991).

In terms of basal area, if we consider the total basal area as a proxy for the degree of cover, the result show a gradient $\left(20-58 \mathrm{~m}^{2} \mathrm{ha}^{-1}\right)$ from recently disturbed plots (right hand

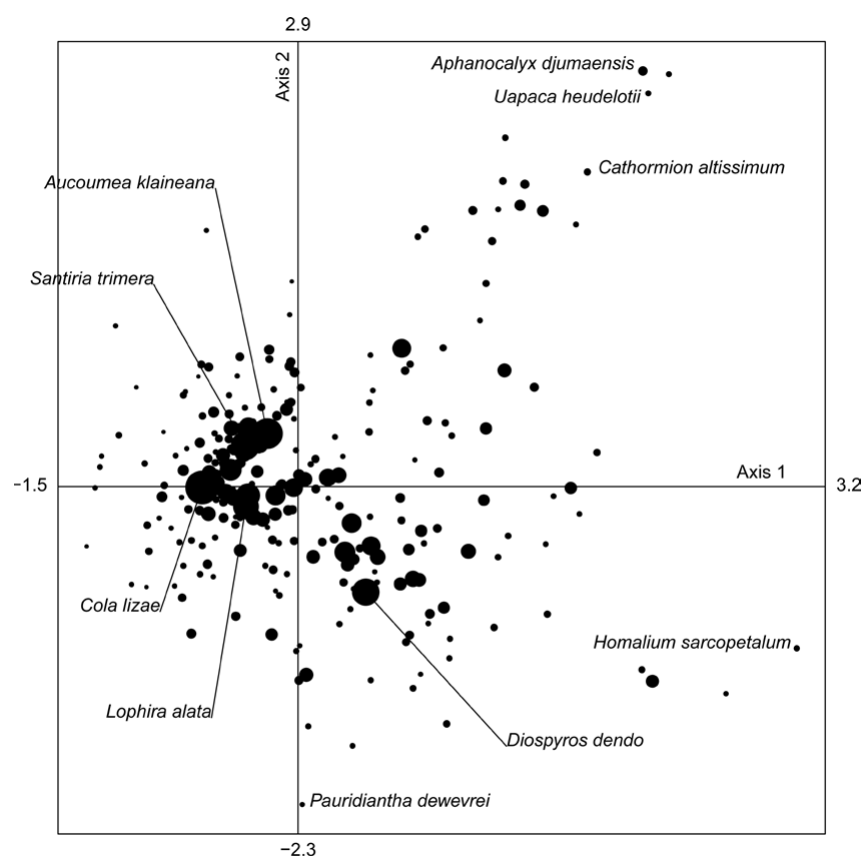

Figure 7 - Projection of species on the first two axes of the canonical correspondence analysis of the species abundances at Lopé, Gabon. The size of dots is proportional to the square root of species abundances. 
side of the gradient) to undisturbed plots (left hand side). These values are found in secondary forest, thus indicating that the five structural group are consistent with secondary forests (Bongers \& Blokland 2004, Nyare 2004). In comparison with the results found in the Itchèdè forest in Benin (Awokou et al. 2009) and in the Una forest in north-eastern Brazil (Faria et al. 2009), the peaks of basal area were obtained for diameters between 35 and $55 \mathrm{~cm}$. We can deduce from this that the structural groups also correspond to an evolution from young secondary forests to old secondary forests (Gazel 1983). In the Dja reserve, Sonké (2004) found values between 26 and $39 \mathrm{~m}^{2} \mathrm{ha}^{-1}$ for the facies of typical heterogeneous forest, whereas in the Maya Biosphere Reserve, basal area varied between 40 and $66 \mathrm{~m}^{2} \mathrm{ha}^{-1}$ depending on the level of disturbance of the plots (Nesheim et al. 2010). In this study, the value of $58 \mathrm{~m}^{2} \mathrm{ha}^{-1}$ in basal area corresponded to floristic group 6 and structural group 5. This value was found for the so-called Maranthaceae forests in the Lopé National Park (White et al. 1995, Nasi 1997).

\section{Floristic characteristics}

A patchy distribution was observed for many species, which also appeared from the comparison of structural group for density, height and basal area. Plots and transects crossed different forest types as described by White (1996) regarding to abiotic factors such as water, rocks, altitude (White 2007). A gradient of forest types was observed (fig. 3): at one end were the floristic groups associated to the river Ogooué; the centre of the gradient corresponded to the colonizing forests and to the forests associated to rocks; and the right hand side of the gradient corresponded to the altitude forests as described by White (1996). This type of gradient was observed in the forests of the plains of South East Liberia and South West Ivory Coast by Van Rompaey \& Oldeman (1996). On the basis of a $\mathrm{CA}$, these authors also evidenced an ordination of the species and plots along a principal gradient.

Similarly to what was observed in Ghana (Hawthorne 1996), the gradient observed on the first axis of the CA (fig. 3) can be interpreted as a 'forest type gradient'. Sometimes this pattern means that the species that compose the forest have a large distribution, which could be investigated by studying their phytogeography. The observed forest recovery also expressed in the structural groups, from the groups with a high species richness in the canopy, a low density but many small individuals (groups 1 and 4), to the dense groups with many large individuals that corresponded to a floristic stability (groups 2 and 5). Between-transect as well as within-transect floristic differences were observed (fig. 5). Nearby plots often had opposite variations. The floristic variations that were evidenced were related to the variations of the forest structure (case of transects 2 and 4). Other studies have also indicated that the species composition may be a better indicator of the forest structure than just diversity (Onaindia et al. 2004 and references therein). This type of results was also obtained in West Indies (Rousteau 1996) when dealing with the variations of species composition and of the forest structure along an altitudinal gradient.

\section{Relationship between structural and floristic characteristics}

Although the observed gradient cannot be explained by structural variables alone, there was a significant relationship between floristic groups and structural groups. This relationship enabled us to distinguish structural groups on the basis of species abundances, with density (with the highest contribution from the small classes $N_{2}$ and $N_{3}$ ) and height being the best discriminating variables. The variations of canopy species diversity and of floristic composition in our study are similar to those obtained by Schulz (1960). Species are locally abundant and globally rare.

Our results suggest that the future development of the forest canopy would involve a slow invasion of the upper canopy by emergent species. Studies on the dynamics of forest formations in the Lopé National Park (White 1996) showed that there was a tendency to monodominant forest types, which is consistent with the typology of secondary forests in Gabon, in particular secondary forests with okoumes (Nyare 2004). The two most exploited tree species in Gabon, Aucoumea klaineana Pierre (okoume) and Dacryodes buettneri (Engl.) H.J.Lam (ozigo), were those with the greatest height in the identified structural groups. This confirms their light-demanding and secondary temperament, and also the strong expansion of okoume as already notified by White et al. (2000) and Born (2007). The characterization of the vegetation groups in the Lopé National Park confirmed that it was composed of secondary forest, and showed that recent disturbances were expressed by floristic associations of species with broad distributions (Hawthorne 1996). Hence, the forest under study at Lopé is a forest mosaic in progression. These results are in agreement with the concept of the silvatic mosaic by Oldeman (1990). Similar results were found in Poland (Bobiec et al. 2000).

The predominance of okoume in the five identified structural groups suggests a tendency to a monodominant climax, in agreement with the forest type described in the Lopé National Park by White (1996). The observed floristic gradient and species abundances can be explained by a local overabundance of light-demanding species. Light is the resource that explains the vertical structure of the forest, the species diversity within the canopy, and the variations of floristic composition across structural groups. Our results evidenced that the forest at Lopé was a dynamic system where forest was recovering, and that the current forest structure was the outcome of the interplay between the forest savanna mosaic on the one hand, and recent and current disturbances on the other hand. In a future work, species traits will be studied in relation with floristic groups at the Lopé National Park, and the evolution of the mosaic will be predicted under a conservatory management plan where fire is used as a tool to maintain the neighbouring savanna.

\section{ACKNOWLEDGEMENTS}

We thank the following people for their contribution in the field, Kathryn J. Jeffery and the technical team field of SEGC. We thank the Centre International de Recherches Médicales de Franceville (CIRMF/SEGC) for logistical support to this study, and UMR 7179 (Brunoy/MNHN) for financially 
supporting our AETFAT conference participation. We thank WCS Gabon, the NERC-UK, the Leverhulme Trust, WOTRO-Netherlands and the Wellcome Trust for funding the data collection for this study.

\section{SUPPLEMENTARY DATA}

Supplementary data are available at Plant Ecology and Evolution, Supplementary Data Site (http://www.ingentaconnect. $\mathrm{com} /$ content/botbel/plecevo/supp-data), and consist of the following: (1) additional multivariate analyses of floristic and structural data (pdf format).

\section{REFERENCES}

Aubréville A.M.A. (1938) La forêt coloniale: les forêts de l'Afrique Occidentale Française. Annales de l'Académie des Sciences Coloniales 9. Paris, Société d'Éditions Géographiques.

Awokou K.S., Ganglo C.J., Azontondé H.A., Adjakidjè V., de Foucault B. (2009) Caractéristiques structurales et écologiques des phytocénoses forestières de la forêt classée d'Itchèdè (département du Plateau, sud-est Bénin). Sciences \& Nature 6: 125138. [available at http://www.ajol.info/index.php/scinat/article/ viewFile/48666/35019]

Bobiec A., van der Burgt H., Meijer K., Zuyderduyn C., Haga J., Vlaanderen B. (2000) Rich deciduous forests in Białowieża as a dynamic mosaic of developmental phases: premises for nature conservation and restoration management. Forest Ecology and Management 130: 159-175. doi:10.1016/S03781127(99)00181-4

Bongers F., Blokland E. (2004) Forêts secondaires: stades de succession écologique et multiples chemins. In: FAO (ed.) Gestion des forêts tropicales secondaires en Afrique francophone: réalité et perspectives. Actes de l'atelier régional $\mathrm{FAO} / \mathrm{IUCN}$, Douala, Cameroun, 17-21 Nov. 2003 : 19-33. Rome, FAO. [available at http://www.fao.org/docrep/007/j2578f/J2578F05. htm\#P1022_78032]

Bormann F.H. (1953) The statistical efficiency of sample plot size and shape in forest ecology. Ecology 34: 474-487. doi: $10.2307 / 1929720$

Born C. (2007) Diversité génétique et dynamique des forêts d'Afrique centrale. Une étude multi-échelle de la structure de la diversité génétique d'un arbre pionnier, Aucoumea klaineana. $\mathrm{PhD}$ Thesis, Université Montpellier II - Sciences et Techniques $\mathrm{du}$ Languedoc, Montpellier, France. [available at http://www. cefe.cnrs.fr/coev/pdf/theses/These_CelineBorn_2007.pdf]

Brown K.A., Gurevitch J. (2004) Long-term impacts of logging on forest diversity in Madagascar. Proceedings of the National Academy of Sciences of the United States of America 101: 6045-6049. doi:10.1073/pnas.0401456101

Clements F.E. (1916) Plant succession: an analysis of the development of vegetation. Publication 242. Washington D.C., USA, Carnegie Institute. available at http://www.archive.org/stream/ cu31924000531818/cu31924000531818_djvu.txt]

Connell J.H. (1978) Diversity in tropical rain forests and coral reefs. Science 199: 1302-1310. doi:10.1126/science.199.4335.1302

Couteron P., Pélissier R., Mapaga D., Molino J.F., Teillier L. (2003) Drawing ecological insights from a management-oriented forest inventory in French Guiana. Forest Ecology and Management 172: 89-108. doi:10.1016/S0378-1127(02)00310-9

Devineau J.L. (1975) Étude quantitative des forêts-galeries de Lamto (moyenne Côte d'Ivoire). PhD Thesis, Université Pierre et Marie Curie (Paris 6), Paris, France. [avai- lable at http://tel.archives-ouvertes.fr/docs/00/36/30/65/PDF/ THESE_3emeCycle_1975.pdf]

Devineau J.L. (1984) Structure et dynamique de quelques forêts tropophiles de l'ouest africain. Travaux des chercheurs de Lamto 5, Programme MAB savanes. [available at http://tel.archivesouvertes.fr/tel-00359023/fr]

Devineau J.L. (1991) Variabilité de la croissance en circonférence des arbres dans les forêts semi-décidues de Lamto (Côte d'Ivoire). Revue d'Écologie (La Terre et la Vie) 46: 95-124. [available at http://hal.archives-ouvertes.fr/ird-00357179/]

Faria D., Mariano-Neto E., Zanforlin Martini A.M., Ortiz J.V., Montingelli R., Rosso S., Barradas Paciencia M.L., Baumgarten J. (2009) Forest structure in a mosaic of rainforest sites: the effect of fragmentation and recovery after clear cut. Forest Ecology and Management 257: 2226-2234. doi:10.1016/j. foreco.2009.02.032

Gazel M. (1983) Croissance des arbres et productivité des peuplements en forêt dense équatoriale de Guyane. Rapport interne. Cayenne, ONF, Direction Régionale de Cayenne.

Hallé F., Oldeman R.A.A., Tomlinson P.B. (1978) Tropical trees and forests: an architectural analysis. Berlin, Springer Verlag.

Härdle W., Simar L. (2003) Applied Multivariate Statistical Analysis. Berlin, Springer-Verlag.

Hawthorne W.D. (1996) Holes and sums of parts in Ghanaian forest: regeneration, scale and sustainable use. Proceedings of the Royal Society of Edinburgh, Series B 104: 75-176.

Lepart J., Escarré J. (1983) La succession végétale, mécanismes et modèles: analyse bibliographique. Bulletin d'Écologie 14: 133-178.

Ministère de l'Éducation Nationale (M.E.N.) de la République Gabonaise (1983) Géographie et cartographie du Gabon - atlas illustré. Paris, Edicef.

Nasi R. (1997) Les peuplements d'okoumé au Gabon. Leur dynamique et croissance en zone côtière. Bois et Forêts des Tropiques 251: 5-27. [available at http://bft.cirad.fr/revues/notice_fr.php?dk=388404]

Nesheim I., Halvorsen R., Nordal I. (2010) Plant composition in the Maya Biosphere Reserve: natural and anthropogenic influences. Plant Ecology 208: 93-122. doi:10.1007/s11258-009-9691-3

Nyare Essima N. (2004) Rapport national du Gabon. In: FAO (ed.) Gestion des forêts tropicales secondaires en Afrique francophone: réalité et perspectives. Actes de l'atelier régional FAO/ IUCN, Douala, Cameroun, 17-21 Nov. 2003: 151-160. Rome, FAO. [available at http://www.fao.org/docrep/007/j2578f/ J2578F17.htm\#P5120_471526]

Oldeman R.A.A. (1974) Écotopes des arbres et gradients écologiques verticaux en forêt guyanaise. La Terre et la Vie, Revue d'Écologie Appliquée 28: 487-520. [available at http://horizon. documentation.ird.fr/exl-doc/pleins_textes/pleins_textes_5/b_ fdi_06-07/07501.pdf]

Oldeman R.A.A. (1990) Forests: elements of sylvology. Berlin, Springer-Verlag.

Onaindia M., Dominguez I., Albizu I., Garbisu C., Amezaga I. (2004) Vegetation diversity and vertical structure as indicators of forest disturbance. Forest Ecology and Management 195: 341-354. doi:10.1016/j.foreco.2004.02.059

Pielou E.C. (1969) An introduction to mathematical ecology. New York, John Wiley \& Sons.

Riéra B., Pélissier R., Houllier F. (1998) Caractérisation d'une mosaïque forestière et de sa dynamique en forêt tropicale humide sempervirente. Biotropica 30: 251-260. doi:10.1111/j.1744-7429.1998.tb00059.x 
Rousteau A. (1996) Structures, flores, dynamiques: réponses des forêts pluviales des Petites Antilles aux milieux montagnards. In: Guillaumet J.L., Belin M., Puig H. (eds) Phytogéographie tropicale: réalités et perspectives. Actes du colloque international de Phytogéographie tropicale, Paris, Juin 1993, Colloques et Séminaires: 307-321. Paris, ORSTOM. [available at http:// www.documentation.ird.fr/hor/fdi:010009702]

Schulz J.P. (1960) Ecological studies on rain forest in Northern Suriname. Verhandelingen der Koninklijke Nederlandse Akademie van Wetenschappen. Afdeling Natuurkunde. Tweede Sectie, Biologie Geneeskunde 53(1): 1-267.

Sonké B. (2004) Forêts de la réserve du Dja (Cameroun): études floristiques et structurales. Scripta Botanica Belgica 32. Meise, Jardin Botanique National de Belgique.

UNESCO (2006) Proposition d'inscription de biens sur la liste du patrimoine mondial. écosystèmes et paysage culturel relique de Lopé-Okanda.

Van Rompaey R.S.A.R., Oldeman R.A.A. (1996) Analyse spatiale $\mathrm{du}$ gradient floristique arborescent dans les forêts de plaine du SE Liberia et SW Côte d'Ivoire. In: Guillaumet J.L., Belin M., Puig H. (eds) Phytogéographie tropicale: réalités et perspectives. Actes du colloque international de Phytogéographie tropicale, Paris, Juin 1993, Colloques et Séminaires: 353-364. Paris, ORSTOM. [available at http://horizon.documentation.ird.fr/ exl-doc/pleins_textes/pleins_textes_6/colloques2/010009705. pdf]

Ward J.H. (1963) Hierarchical grouping to optimize an objective function. Journal of the American Statistical Association 58: 236-244. doi:10.2307/2282967

White E.C. (2007) Ecology of Mandrillus sphinx: ranging, diet and social structure of a Mandrill horde in Lopé National Park, Ga- bon. Ph.D. thesis, University of Exeter, Cornwall, United Kingdom.

White L.J.T. (1992) Vegetation history and logging disturbance: effects on rain forest mammals in the Lopé Reserve, Gabon. PhD thesis, University of Edinburgh, Edinburgh, United Kingdom.

White L.J.T. (1996) Étude de la végétation - Rapport final. Projet ECOFAC - composante Gabon. Libreville, AGRECO / CTFT.

White L.J.T., Oslisly R., Abernethy K., Maley J. (2000) L'okoumé (Aucoumea klaineana): expansion et déclin d'un arbre pionnier en Afrique centrale atlantique au cours de l'Holocène. In: Servant M., Servant-Vildary S. (eds) Dynamique à long terme des écosystèmes forestiers intertropicaux: Symposium international, 20-22 Mars 1996, Paris: 399-411. Paris, UNESCO. [available at http://horizon.documentation.ird.fr/exl-doc/pleins textes/pleins_textes_7/carton01/010007595.pdf]

White L.J.T., Rogers M.E., Tutin C.E.G., Williamson E.A., Fernandez M. (1995) Herbaceous vegetation in different forest types in the Lopé Reserve, Gabon: implications for keystone food availability. African Journal of Ecology 33: 124-141. doi:10.1111/j.1365-2028.1995.tb00788.x

Whitmore T.C. (1975) Tropical rain forests of the Far East. Oxford, UK, Clarendon Press/Oxford University Press.

Paper based on results presented during the XIX ${ }^{\text {th }}$ AETFAT Congress (Madagascar 2010). Manuscript received 14 Jul. 2010; accepted in revised version 16 Feb. 2011. This paper will be reprinted in the Proceedings of the XIX ${ }^{\text {th }}$ AETFAT Congress.

Communicating Editors: Brice Sinsin \& Elmar Robbrecht. 